\title{
An underwater tracking system for mapping marine communities: an application to Posidonia oceanica
}

\section{Une méthode de navigation sous-marine utilisée pour la cartographie des biocénoses marines : application à Posidonia oceanica}

\author{
Sergio Sgorbini *, Andrea Peirano, Silvia Cocito, Massimo Morgigni \\ ENEA-Marine Environment Research Centre, PO Box 224, 19100 La Spezia, Italy
}

Received 10 December 2001; received in revised form 14 March 2002; accepted 14 March 2002

\begin{abstract}
The GPS intelligent buoy is a portable underwater tracking system consisting of four buoys and one pinger. The pinger was mounted on an underwater vehicle driven by a scuba diver and used to map the limits of a Posidonia oceanica meadow. To test the accuracy of the method the system was tried out on different types of limits and on healthy and regressed part of the meadow from 2 to $25 \mathrm{~m}$ of depth. The time of track acquisition (1 point per second), the recording speed $\left(1 \mathrm{~km} \mathrm{~h}^{-1}\right)$ and the mapping scale (more than 1:500) indicated that the proposed method may be successfully integrated with conventional systems for mapping marine communities. (C) 2002 Ifremer/CNRS/IRD/Éditions scientifiques et médicales Elsevier SAS. All rights reserved.
\end{abstract}

\section{Résumé}

La «bouée intelligente » à GPS est un système portable de navigation sous-marine constitué de quatre bouées et d'un émetteur acoustique. L'émetteur acoustique a été installé sur un véhicule sous-marin ; conduit par un plongeur, il suit la limite de l'herbier à Posidonia oceanica. Pour vérifier la précision de cette méthode, le système a été testé entre 2 et 25 mètres de profondeur sur différents types d'herbiers. La fréquence d'acquisition de la trace (un point par seconde), la vitesse d'acquisition (un kilométre heure) et la précision obtenue (échelle >1:500) indiquent que cette méthode peut être utilisée pour améliorer les techniques actuelles de cartographie sous-marine. (C) 2002 Ifremer/CNRS/IRD/Éditions scientifiques et médicales Elsevier SAS. Tous droits réservés.

Keywords: Mapping; Seagrass; Posidonia oceanica; Mediterranean Sea

Mots clés: Cartographie; Phanérogames marines; Posidonia oceanica; Méditerranée

\section{Introduction}

The knowledge of the occurrence, extension and limits of submerged marine ecosystems has a primary importance both for scientific and coastal management purposes and large-scale mapping programs have focused on major coastal biological indicators as mangroves, coral reefs, macroalgae and seagrass beds (Meinesz and Laurent, 1978;

\footnotetext{
* Corresponding author.

E-mail address: sgorbini@santateresa.enea.it (S. Sgorbini).
}

Augier, 1986; Belsher et al., 1996; Green et al., 2000; Chavaud et al., 2001).

Usually, best results in mapping marine communities are achieved through the combination of direct (visual) and indirect (instrumental) mapping techniques, the two approaches being not exclusive but complementary. Visual methods include survey conducted with remotely operated vehicle (ROV), towed camera, scuba and snorkelling divers following fixed, underwater transects (Stoddart, 1978; Belsher et al., 1998; Belsher and Houlgatte, 2000). Indirect (instrumental) methods are based mainly on side scan sonar 
(SSS) surveys and remote sensing (aerial and satellite imagery) (Kirkman, 1990; Meinesz et al., 1991; Belsher et al., 1996). Although remote sensing and SSS are the most effective mapping methods, in terms of surface covered per day, they always need the direct validation of mapped targets. Moreover, imagery techniques are nullified by the presence of turbid water and SSS surveys could be heavily limited by steep bottoms, shallow rocky bottoms or in little bays where obstacles (buoys, anchorages, shoals, etc.) interfere with the regular boat course. In these constraints, the contours of marine communities are normally mapped with interpolations of limits detected by visual methods. However, one of the main problems in diving operations is the difficulty to obtain an accuracy in underwater positioning comparable to indirect methods, a problem that can be solved in shallow water using a number of limited, fixed markers (Augier, 1986; Calvo et al., 1993).

The aim of this work is to present an application of a rapid and accurate technique to record and map in real time, by scuba diving, both in shallow and in deep water, the contour of marine communities. The method was applied to map the seagrass bed of Posidonia oceanica, one of the most important Mediterranean coastal communities. The resulting map is compared with a previous one obtained by actual methods. Efficacy of the method and its constraints are discussed.

\section{Materials and methods}

\subsection{The GPS intelligent buoys}

The GPS intelligent buoy (GIB) is a portable tracking system manufactured by Orca (Brest, France) that consists of one underwater pinger, four buoys and a receiving (deck) unit (fig. 1). The system works on the principle of 'long baseline' system with the GPS differential correction (Thomas, 1994). The pinger emits a signal at $32 \mathrm{kHz}$, one pulse per second, that is detected by the four buoys (Fig. 1a) that, by turn, transmit their distances from the pinger to the deck unit. The maximum distance between two buoys is $1.5 \mathrm{~km}$. The autonomy of the system depends mainly on the battery pack of the pinger (about $20 \mathrm{~h}$ ). Onboard, the scientist follows in real time on the PC monitor the position, depth and tracking of the pinger. The system has an accuracy of $0.5 \mathrm{~m}$ on a fixed point (Fig. 1b). In our experiment, the pinger was mounted on a pole fixed to an underwater scooter and the diver followed the limits of the meadow (Fig. 1c). During the survey, the diver stopped when he decided to note the characteristic of the meadow on one plastic board fixed to the underwater vehicle. In each note, he reported also the stopping time and the depth of recording. All the data recorded underwater were then coupled with the mapping data for an exhaustive description of the meadow.
Accuracy of the tracking method was evaluated both on upper and lower meadow limits. The resulting $P$. oceanica contour was compared with the previous map to evidence benefits and constraints of the GIB continuous recording method.

\subsection{The study site}

We experimented the GIB system on the P. oceanica meadow of the Bay of Monterosso al Mare, in the Marine National Park of '5 Terre' (La Spezia, N-W Mediterranean Sea). The meadow covers a surface of nearly 30 ha from 2 to $25 \mathrm{~m}$ of depth and presents different limits due both to different types of substrata (rocks, coralligenous rocks, sand and fine sands) and to anthropogenic stress. One embankment divides the meadow in two zones: the western part, where $P$. oceanica cover attains $100 \%$, and the eastern more regressed part, where cover never exceeds $25 \%$ (Fig. 1d). Due to its narrow form and the presence of rocky shoals and anchorages, the meadow could only be mapped through 11 scuba diving transects, spot checks and interpolation technique (Cavazza et al., 2000).

\section{Results and discussion}

The four buoys of the GIB system, covering an area of nearly $1.6 \mathrm{~km}^{2}$, were deployed in the study site in $20 \mathrm{~min}$ (Fig. 1d). The diver followed the entire limit of the $P$. oceanica meadow in two successive dives. The estimated underwater recording speed was about $1 \mathrm{~m} \mathrm{~s}^{-1}$, thus allowing the mapping of $1 \mathrm{~km}$ of the seagrass contour in $1 \mathrm{~h}$.

On the nearshore P. oceanica limit, formed by sparse hills of the seagrass, or 'herbier de colline' following Boudoresque et al. (1985), two track replicates were performed at $4-5 \mathrm{~m}$ of depth. Differences between the two tracks were $2.45 \pm 0.33 \mathrm{~m}$ (Fig. 1d-1).

On the deeper part of the meadow, tracks were compared on two types of limits (Meinesz and Laurent, 1978) on sand and fine sand: type B regressed limit, with eroded matte, and little 'islands' of seagrass ( $50 \%>$ cover $>75 \%)$ and type C limit, with dense $P$. oceanica bed (cover $>75 \%$ ) with a step of eroded 'matte' $0.5-1 \mathrm{~m}$ high. Type $\mathrm{C}$ and $\mathrm{B}$ limits track replicates gave similar results, respectively, $0.63 \pm 0.38 \mathrm{~m}$ and $0.25 \pm 0.28 \mathrm{~m}$ (Fig. 1d-2, d-3). We were not able to map the eastern, heavily regressed part of the meadow. The type A limit (Meinesz and Laurent, 1978), characterised by a cover less than 5\% and sparse, single, deep shoots did not allow the diver to follow a regular course.

The comparison between the P. oceanica map obtained with the GIB system and the previous map obtained with the transects and the interpolating technique (Cavazza et al., 2000) evidenced that the GIB + diver technique produced a higher level of detail in contouring both the upper and the lower limits (Fig. 1d). 

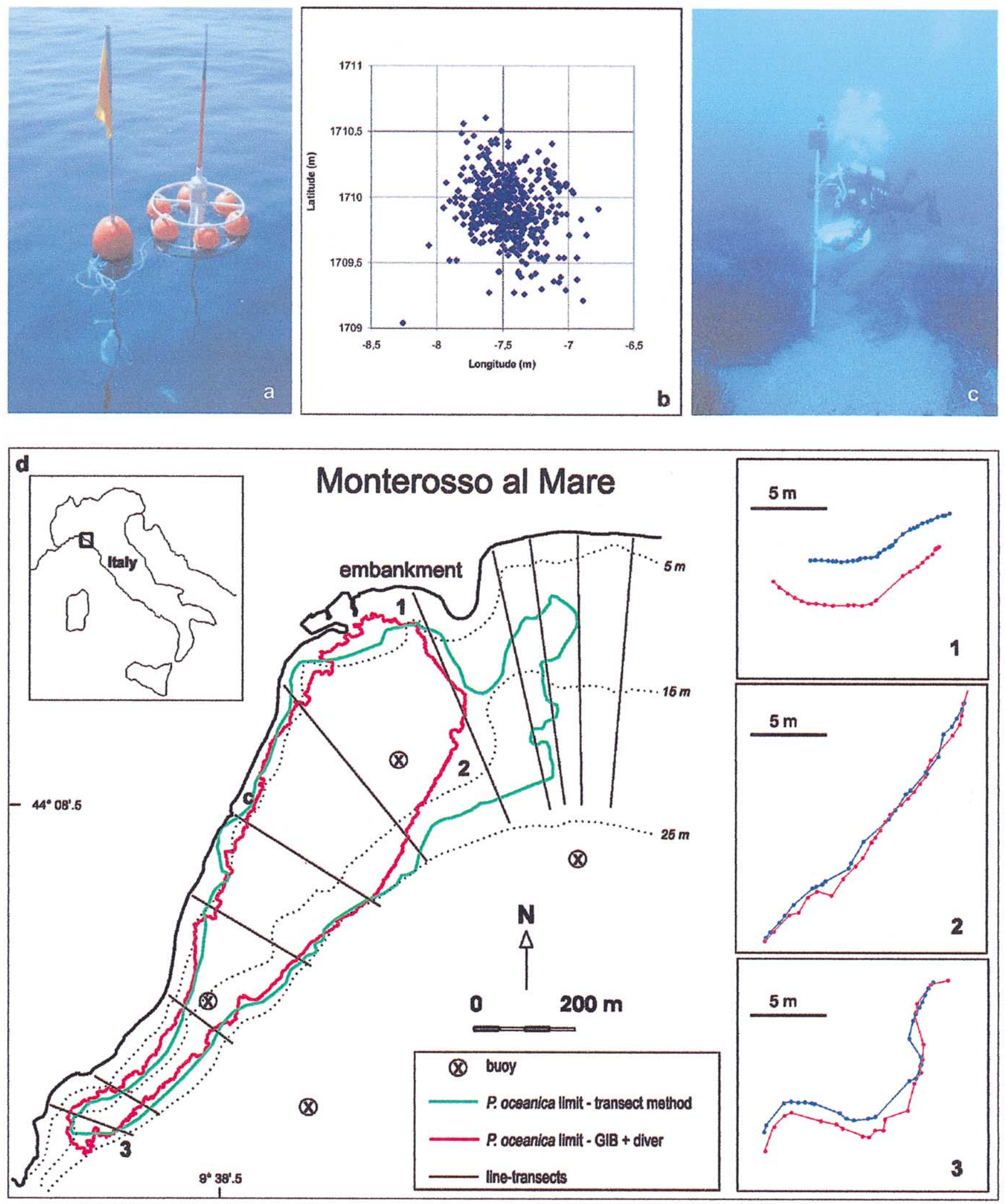

Fig. 1. Components of the GPS intelligent buoys system: (a) one of the four buoys; (b) accuracy of underwater positioning of one fixed point (grid size: $0.5 \mathrm{~m}$ ); (c) the pinger fixed to an underwater scuba diving vehicle; (d) comparison between the contour of Posidonia oceanica meadow detected through the GIB system (red line) and the map resulting from interpolations of data collected following the line-transect method (green line). In close-up, details of the three types of limit investigated in two successive replicates: (d-1) shallow, sparse hills of seagrass; (d-2) deep, regressive limit; (d-3) deep, eroded limit. 
The efficiency of the method was satisfactory, both for the accuracy of the measurements and for its easy and quick procedure which allow us to obtain geo-referenced data with a precision higher than imagery systems. For its high scale of resolution (>1:500), the proposed technique allows the rapid collection of data on the contour and limits of seagrass beds. This system, which can work also positioned on a towed camera or on ROV, is, because of its rapidity in deployment and collecting data, particularly suitable both for long term monitoring and when mapping impacts on seagrass beds and other marine ecosystems in case of pollution, dredging, landslides, aquaculture, tourism impact and invasive organisms are required. Finally, considering the efficiency and versatility of the system, in which buoys can be deployed by a rubber boat and the deck unit can also be positioned on land, the costs of coastal surveys become more economical, both in terms of time and number of operators engaged.

\section{Acknowledgements}

The work has been developed thanks to the sustainment of the program, Ambiente Mediterraneo (Accordo di programma CNR-MURST, L. 95/95). A special thanks to A. Bruschi (Enea, La Spezia) for his critical contribution and to T. Belsher (Ifremer, Brest) and A. Meinesz (LEML, NiceSophia Antipolis) for the critical review of the manuscript.

\section{References}

Augier, H., 1986. L'herbier à Posidonia oceanica, son importance pour le littoral méditerranéen, sa valeur comme indicateur biologique de l'état de santé de la mer, son utilisation dans la surveillance du milieu, les bilans écologiques et les études d'impact. Vie Marine 7, 85-113.

Belsher, T., Lavoie, A., Dubois, J.N., 1996. La végétation marine, répartition, biomasse et gestion. Précis de télédétection, Application thématiques, Presse de l'Univ. du Quebec, UREF, AUPELF, 2, pp. $428-474$.
Belsher, T., Dimeet, J., Raillard, J.M., Emery, E., Boutbien, M., Prudhomme, C., Pucci, R., 1998. Acquisition d'éléments qualitatifs et quantitatifs sur l'invasion de Caulerpa taxifolia en 1996 (Alpes Maritimes, Var et Pricipauté de Monaco). In: Boudouresque, C.F., Gravez, V., Meinesz, A., Paully, F. (Eds.), Third International Workshop on Caulerpa taxifolia, GIS Posidonie publ., France. pp. $33-43$.

Belsher, T., Houlgatte, E., 2000. Etude des sédiments superficiels marins des herbiers à phanérogames et des peuplements à Caulerpa taxifolia de Menton au cap d'Ail. Editions Ifremer, Brest, France.

Boudouresque, C.F., Jeudy De Grissac, A., Meinesz, A., 1985. Un nouveau type d'herbier à Posidonia oceanica: l'herbier de colline. Rapp. Comm. Int. Mer Médit. 29 (5), 173-175.

Calvo, S., Fradà Orestano, C., Abbadessa, P., 1993. The suitability of a topographical instrument for an integrated approach to the cartography of Posidonia oceanica meadows. Oceanol. Acta 16 (3), 273-278.

Cavazza, W., Immordino, F., Moretti, L., Peirano, A., Pironi, A., Ruggiero, F., 2000. Sedimentological parameters and seagrasses distribution as indicators of anthropogenic coastal degradation at Monterosso Bay (Ligurian Sea, NW Italy). J. Coast. Res. 16 (29), 295-305.

Chavaud, S., Bouchon, C., Manière, R., 2001. Cartographie des biocénoses marines de Guadeloupe à partir de donées SPOT (récifs coralliens, phanérogames marines, mangroves). Oceanol. Acta 24 (Suppl.), $3-16$.

Green, P.E., Mumby, P.J., Edwards, A.J., Clark, C.D., 2000. Remote sensing handbook for tropical coastal management. Coastal management sourcebook 3. UNESCO publishing, Paris.

Kirkman, H., 1990. Seagrass distribution and mapping. In: Phillips, R.C., Mc Roy, C.P. (Eds.), Seagrass Research Methods. Monographs on oceanographic methodology, UNESCO. pp. 19-25.

Meinesz, A., Laurent, R., 1978. Cartographie et état de la limite inférieure de l'herbier de Posidonia oceanica dans les Alpes-maritimes (France). Campagne Poséidon 1976. Bot. Mar. 21 (8), 513-526.

Meinesz, A., Belsher, T., Boudouresque, C.F., Lefevre, J.R., 1991. Premiére évaluation des potentialités du satellite SPOT pour la cartographie des peuplements benthiques superficiels du Méditerranée occidentale. Oceanol. Acta 4 (3), 299-307.

Stoddart, D.R., 1978. Mapping reef and islands. In: Stoddart, D.R., Johannes, R.E. (Eds.), Coral Reefs Research Methods. Monographs on Oceanographic Methodology, UNESCO. pp. 17-22.

Thomas, H., 1994. New Advanced Underwater Navigation Techniques Based on Surface Relay Buoys, OCEAN 94 Osates, Brest. 